\title{
Tree-Dwelling Ants: Contrasting Two Brazilian Cerrado Plant Species without Extrafloral Nectaries
}

\author{
Jonas Maravalhas, ${ }^{1}$ Jacques H. C. Delabie, ${ }^{2}$ Rafael G. Macedo, ${ }^{1}$ and Helena C. Morais ${ }^{1}$ \\ ${ }^{1}$ Departamento de Ecologia, Instituto de Biologia, Universidade de Brasília, 70910-900 Brasília, DF, Brazil \\ ${ }^{2}$ Laboratório de Mirmecologia, Convênio UESC/CEPLAC, Centro de Pesquisa do Cacau, CEPLAC, CX. P. 07, \\ 45600-000 Itabuna, BA, Brazil
}

Correspondence should be addressed to Jonas Maravalhas, jmaravalhas@gmail.com

Received 31 May 2011; Revised 28 June 2011; Accepted 30 June 2011

Academic Editor: Fernando Fernández

Copyright (C) 2012 Jonas Maravalhas et al. This is an open access article distributed under the Creative Commons Attribution License, which permits unrestricted use, distribution, and reproduction in any medium, provided the original work is properly cited.

Ants dominate vegetation stratum, exploiting resources like extrafloral nectaries (EFNs) and insect honeydew. These interactions are frequent in Brazilian cerrado and are well known, but few studies compare ant fauna and explored resources between plant species. We surveyed two cerrado plants without EFNs, Roupala montana (found on preserved environments of our study area) and Solanum lycocarpum (disturbed ones). Ants were collected and identified, and resources on each plant noted. Ant frequency and richness were higher on $R$. montana (67\%; $35 \mathrm{spp})$ than $S$. lycocarpum (52\%; 26), the occurrence of the common ant species varied between them, and similarity was low. Resources were explored mainly by Camponotus crassus and consisted of scale insects, aphids, and floral nectaries on R. montana and two treehopper species on S. lycocarpum. Ants have a high diversity on cerrado plants, exploring liquid and prey-based resources that vary in time and space and affect their presence on plants.

\section{Introduction}

Foliage-dwelling ants are an important component in tropical environments [1-3], affecting locally the composition and abundance of other insect communities [4-6] and directly or indirectly driving mutualistic and trophic interactions in plant-herbivore-predator/parasite interactions [711]. High abundance and richness of ants on this stratum are due to a highly energetic liquid diet, mainly extrafloral nectaries (EFNs) and hemipteran honeydew [12-14]. Ants use a variety of resources from plants and their herbivores and these associations are facultative and vary temporally and spatially [1].

In the cerrado, a savanna-like vegetation in central Brazil, there is a high proportion of plants bearing EFNs, representing up to $31 \%$ of the plant individuals surveyed $[15,16]$ and a rich fauna of ants exploiting them $[2,17-$ 19]. A vast literature about direct and indirect associations of ants and plants in this biome is available [20], but there are few studies comparing ant faunas and their resources between plant species, especially those without EFNs. Results presented by Schoereder et al. [2] indicate that the presence of EFNs does not affect ant species richness within a given tree and there is no particular ant species composition typical of plants with EFNs.

To link the richness and seasonal variation of ants to attractive resources available on a particular plant species, we compared ant assemblages on two species that do not bear EFNs and are common of the cerrado region of central Brazil: Roupala montana Aubl. (Proteaceae) and Solanum lycocarpum St. Hill. (Solanaceae). In our sampling area, both plants have similar stature and structure, are consumed by myrmecophilous hemipterans [21, 22], and were found in different environments: $R$. montana occurring in native cerrado vegetation, where $S$. lycocarpum is rarely found, being common in altered areas at the borders of roads and agropastoral fields. The ability of S. lycocarpum to establish itself in a wider range of environments supposedly leads to bigger ant richness, in contrast to $R$. montana. On the other hand, impoverished areas, where $S$. lycocarpum occurs, can sustain weaker ant diversity, which can affect the ant fauna foraging on this species. We expect that differences 
on the area of occurrence and resource availability between these plant species may lead to important differences in the composition of ant species.

\section{Material and Methods}

2.1. Study Area. This study was conducted in the Fazenda Agua Limpa ( $\left.15^{\circ} 57^{\prime} \mathrm{S}, 47^{\circ} 54^{\prime} \mathrm{W}\right)$, Federal District, Brazil. This 4,500 ha farm belongs to the University of Brasilia and includes mainly undisturbed cerrado vegetation and agro-silvo-pastoral experimental areas. The region has altitudes around $1,050 \mathrm{~m}$ a.s.l., average annual temperature of $22^{\circ} \mathrm{C}$, and average annual rainfall of $1,417 \mathrm{~mm}$ (series from 1980 to 2004, data from RECOR Meteorological Station, http://www.recor.org.br/), and a marked seasonality, with a lengthy dry season ranging from May to September and a wet season from October to April.

2.2. Plant Species. Roupala montana is widely distributed in the Brazilian cerrado [23] and is abundant in cerrado remnants of the Federal District. It is an evergreen shrub that simultaneously sheds leaves and produces new ones, reaching up to three meters height, blooms for a long period during the year, and is pollinated by moths [24-26]. It hosts ant-tended hemipterans like scale insects (Coccoidea), aphids (Aphidoidea), and, especially a leafhopper species, Rotundicerus sp. (Cicadellidae and Idiocerinae), which forms large aggregates of nymphs feeding on new leaves at the beginning of the rainy season [21]. A rich fauna of caterpillars, including Hallonympha paucipuncta (Spitz, 1930) (Riodinidae) and at least 10 species of Lycaenidae, consumes its leaves and inflorescences [27-29].

Solanum lycocarpum is an evergreen shrub with maximum height of about two meters, being extremely common in disturbed environments [30,31]. New leaves and flowers grow throughout the year, but flowers do not reward nectar to insects, and pollen is the floral resource collected by bumblebees through buzz pollination behavior [30]. Leaf surfaces are covered with simple glandular and nonglandular trichomes and stellate trichomes [32]. The treehopper Enchenopa brasiliensis Strümpel, 2007 (Membracidae) is a common species feeding on apical meristems and inflorescences [22]. In the study area, two species of Membracidae, one of Aetalionidae and an inderterminated number of species of scale insects were tended by ants on new leaves of this plant. One Cicadelidae species was very abundant too on the same plants, but it was not associated with ants. Solanum lycocarpum leaves are eaten by several microlepidoptera, especially Symmetrischema chloroneura (Meyrick, 1923) (Gelechiidae) [33], its stems are consumed by gall-forming weevil, Collabismus clitellae Boheman, 1837 (Curculionidae) [34] and its leaves and fruits are eaten by several species of mammals [31, 35-37]. Attini nests (Formicidae and Myrmicinae) favor the establishment of seedlings and enhance nutrient in the leaves of S. lycocarpum [38].

2.3. Samples and Data Analysis. Individuals of both plant species were carefully examined always in the morning
TABLE 1: Frequency of occurrence of ants and myrmecophilous hemipterans on Roupala montana (Proteaceae) and Solanum lycocarpum (Solanaceae), in Fazenda Agua Limpa, Federal District, Brazil. Comparisons made with contingency tables.

\begin{tabular}{|c|c|c|c|c|}
\hline Caracteristics & Roupala & Solanum & $x^{2}$ & $P$ \\
\hline Examined plants & 327 & 431 & & \\
\hline Plants with ants & 218 & 226 & 15.517 & 0.0001 \\
\hline $\begin{array}{l}\text { Plants with myrmecophilous } \\
\text { hemipterans }\end{array}$ & 139 & 188 & 0.094 & 0.816 \\
\hline $\begin{array}{l}\text { Co-occurrence of ants and } \\
\text { hemipterans }\end{array}$ & 115 & 143 & 0.328 & 0.620 \\
\hline $\begin{array}{l}\text { Plants with hemipterans } \\
\text { without ants }\end{array}$ & 24 & 45 & 2.161 & 0.141 \\
\hline $\begin{array}{l}\text { Plants with ants without } \\
\text { hemipterans }\end{array}$ & 103 & 83 & 15.046 & 0.0001 \\
\hline
\end{tabular}

period. Every ant observed on the plant was collected and the occurrence of myrmecophilous hemipterans registered. Roupala montana plants $(n=327)$ were examined between April and September (dry season) of 2007 in a typical cerrado vegetation area of 2 ha. Previous surveys in the same study area were made on this species during the wet season of 2006, when the focus was to collect the ants tending nymphs of Rotundicerus sp. $(n=116)$. Solanum lycocarpum plants $(n=431)$ were inspected between March 2007 and March 2008 along dirt roads that cross a mosaic of environments, including typical and "campo sujo" (a physiognomy dominated by herbaceous vegetation) native cerrado areas, pastures and cultures of coffee, sorghum, and pine. The sampling area of $S$. lycocarpum was more widely spread than that of $R$. montana.

The mean similarity of ant species composition between the two plant species was calculated by grouping the samples of each month from April and October $(n=7)$. The similarity indexes and rarefaction curves were generated using EstimateS [39]. The frequency tests were made using BioEstat 5.0 [40].

\section{Results}

Ants were more frequent on R. montana (67\%) as compared to $S$. lycocarpum (52\%) and this difference was due to higher occurrence of ants on $R$. montana plants without myrmecophilous hemipterans (Table 1). Along the study we collected a total of 45 ant species from 11 different genera. We recorded 35 species on $R$. montana and 26 on $S$. lycocarpum, with estimated richness (first order Jackknife \pm standard deviation) of $40( \pm 2.6)$ and $29( \pm 2.3)$, respectively, (Figure 1; Table 2).

The frequency of occurrence of the most common ant species were different on the two plant species (Table 2) and the mean similarity $( \pm \mathrm{sd})$ of the ant assemblages for the dry season was low (Sorensen Index $=0.419 \pm 0.078$ ), especially when the frequency of occurrence of ant species was considered (Morisita-Horn Index $=0.372 \pm 0.167$ ). 


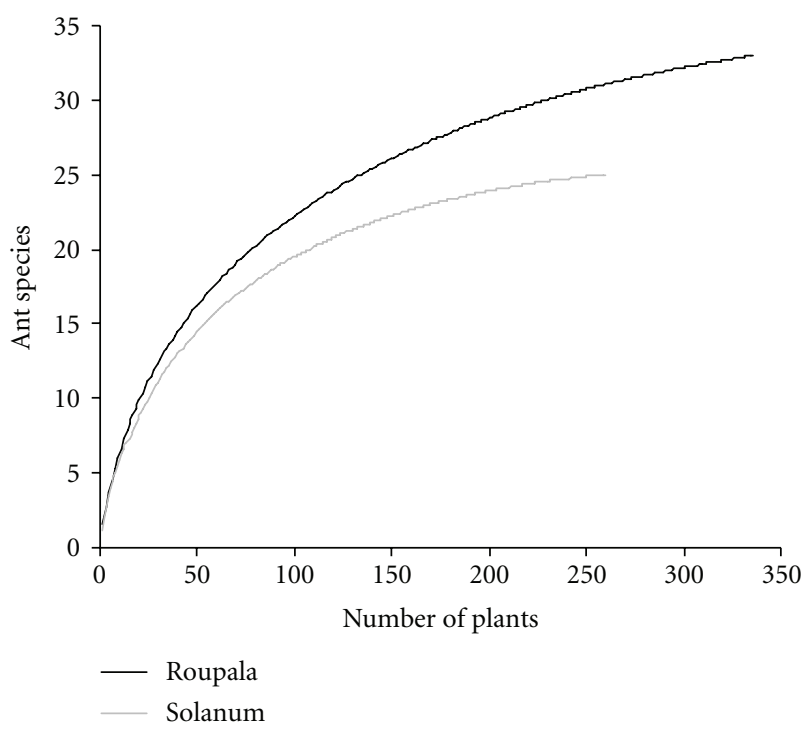

FIgURE 1: Rarefaction curves of ant species collected on Roupala montana (Proteaceae) and Solanum lycocarpum (Solanaceae), in Fazenda Agua Limpa, Federal District, Brazil.

Scale insects were an abundant resource in the leaves of R. montana, being found throughout the sampling period and $21 \%$ of ants in this plant were exploring this resource. We found 15 species of ants attending scale insects, and the most frequent were Cephalotes pusillus (Klug, 1824) (17 occurrences), Camponotus crassus (Mayr, 1862) (8), Brachymyrmex sp. (7), Crematogaster evallans (Forel, 1907) (6), and Solenopsis sp. (5). Some individuals of R. montana were flowering between April and July 2007 and developing inflorescences were explored by aphids, associated to four ant species, mainly Cr. evallans (4) and Camponotus (Myrmaphaenus) sp.2 (3). Seven species were recorded exploring mature floral nectaries, mostly Ce. pusillus (5) and Camponotus (Myrmaphaenus) sp.2 (4).

The frequency of occurrence of the commonest ant species was different on $R$. montana with and without Rotundicerus sp. A large proportion (67\%) of the R. montana individuals examined during the dry season had ants, and $68 \%$ of the groups of Rotundicerus sp. on the same plant species and in the same area where tended by ants during the rainy season of 2006. Although the occurrence of the leafhopper did not enhance the frequency of visits of ants, it altered the composition of the ant fauna. The most notable cases were Ca. crassus and Azteca instabilis (Smith, 1862), which increased their frequency on the plants when Rotundicerus sp. was present, from 4 to $28 \%$ and 0 to $10 \%$, respectively. Cephalotes pusillus and Crematogaster stollii Forel, 1885, on the other hand, decreased their frequency from $19 \%$ to $8 \%$ and from $7 \%$ to $0 \%$, respectively.

Major resources explored by ants in S. lycocarpum were two species of Membracidae, each one present in $23 \%$ of the examined plants and $\mathrm{Ca}$. crassus was the most frequent ant found in association with them. One species of Aetalionidae and scale insects were infrequent on this plant, being seen three and seven times, respectively. We lack nutritional information of glandular trichomes of $S$. lycocarpum, but small ants, like some species belonging to the genera Brachymyrmex, Dorymyrmex, Pheidole, and Solenopsis, possibly use this resource. Pseudomyrmex spp. were generally present $(68 \%)$ on plants without myrmecophilous hemipterans.

\section{Discussion}

We found a high frequency of plants visited by ants, showing the prevalence of ants foraging on cerrado plants, even during the dry season, when $R$. montana plants were examined. The high availability of potential resources for ants $[2,13,41]$, especially myrmecophilous hemipterans in the cerrado vegetation $[21,22,42,43]$, makes this stratum attractive to ants. Even with the predominance of liquid diet, it is important to stress that various species of ants forage for preys on plants, including myrmecophilous hemipterans [44]. In an urban area of Campinas (SP), for example, 70\% of the diet of Pseudomyrmex gracilis (Fabricius, 1804) was based on arthropods, primarily a Psyllidae species (Hemiptera and Sternorryncha) [45]. This can explain the high frequency of Pseudomyrmex spp. in the samples, as well as the presence of Pachycondyla spp., a genus of predator ants [46]. Besides, some genera (e.g., Cephalotes and Pseudomyrmex) nest in dried plant branches, and this too can affect the ant assemblage that forage on an individual plant.

Richness of ants was high in both plant species, especially considering that the surveys were conducted only in the morning. Studies including day and night time observations, showed an average of 21 ant species visiting EFNs on six species of cerrado plants, with a minimum of nine on Qualea multiflora Mart. (Vochysiaceae) and a maximum of 34 on Caryocar brasiliense Camb. (Caryocaraceae) (Appendix 6.1 in [1]). Sequential samplings on Schefflera vinosa (Cham. \& Schltdl.) Frondin and Fiasch (Araliacae) revealed that Guayaquila xiphias (Fabricius, 1803) treehoppers are attended day and night by 21 species of honeydew-gathering ants [42], whereas shrubs of Solanum lycocarpum hosting Enchenopa brasiliensis treehoppers are regularly visited by 10 ant species [22]. Campos et al. [19], using pitfall traps in a cerrado area of the state of Goias, found 16 species of ants on the shrub stratum (height between 0.5 and $1.5 \mathrm{~m}$ ) and 28 on the arboreal stratum (dominated by taller, mature trees).

As expected, ant fauna between the two plants species investigated showed small similarity. The different habitats of occurrence of the plants undoubtedly had an effect on this result [47-50], but variation on resource availability might have an important influence on the composition of ant species [41]. So there must be a particular ant species composition typical of plants with these kinds of resources (e.g., big groups of myrmecophilous hemipterans and active EFNs) even though for a limited period of time. Probably the fidelity of dominant ants plays a key role in structuring assemblages of tending ants on this rich food resource. Hence, comparisons on the frequency of occurrence and composition of species of ants on plants with and without these resources need to be done when they are present 
Table 2: Ant species and its occurrence on Roupala montana (Proteaceae) and Solanum lycocarpum (Solanaceae), in Fazenda Agua Limpa, Federal District, Brazil. The most frequent species are highlighted.

\begin{tabular}{|c|c|c|}
\hline Formicidae & Roupala & Solanum \\
\hline \multicolumn{3}{|c|}{ Myrmicinae } \\
\hline Cephalotes adolphi Emery & 2 & 0 \\
\hline Cephalotes atratus Linnaeus & 0 & 2 \\
\hline Cephalotes betoi De Andrade & 3 & 0 \\
\hline Cephalotes depressus (Klug) & 5 & 10 \\
\hline Cephalotes grandinosus (Smith) & 6 & 0 \\
\hline Cephalotes liepini de Andrade \& Baroni Urbani & 2 & 0 \\
\hline Cephalotes pusillus (Klug) & 147 & 18 \\
\hline Crematogaster distans Mayr & 3 & 6 \\
\hline Crematogaster evallans Forel & 11 & 3 \\
\hline Crematogaster stollii Forel & 14 & 0 \\
\hline Crematogaster victima (Smith) & 1 & 0 \\
\hline Crematogaster sp. & 3 & 0 \\
\hline Nesomyrmex pleuriticus (Wheeler) & 1 & 0 \\
\hline Nesomyrmex tristani Emery & 1 & 0 \\
\hline Pheidole capillata Emery & 10 & 7 \\
\hline Pheidole sp.1 grupo fallax & 2 & 1 \\
\hline Solenopsis substituta (Santschi) & 0 & 9 \\
\hline Solenopsis sp. & 12 & 0 \\
\hline \multicolumn{3}{|c|}{ Formicinae } \\
\hline Brachymyrmex sp. & 14 & 9 \\
\hline Camponotus arboreus (Smith) & 4 & 0 \\
\hline Camponotus atriceps (Smith) & 2 & 0 \\
\hline Camponotus blandus (Smith) & 1 & 2 \\
\hline Camponotus crassus Mayr & 64 & 105 \\
\hline Camponotus fastigatus Roger & 0 & 2 \\
\hline Camponotus melanoticus Emery & 1 & 5 \\
\hline Camponotus novogranadensis Mayr & 3 & 0 \\
\hline Camponotus rufipes Fabricius & $\mathbf{0}$ & 38 \\
\hline Camponotus (Myrmaphaenus) sp.1 & 1 & 3 \\
\hline Camponotus (Myrmaphaenus) sp.2 & 34 & 2 \\
\hline Camponotus (Myrmaphaenus) sp.3 & 0 & 1 \\
\hline Camponotus (Myrmaphaenus) sp.4 & 0 & 3 \\
\hline Camponotus (Myrmobrachys) sp.1 & 1 & 0 \\
\hline Camponotus (Myrmobrachys) sp.2 & 2 & 0 \\
\hline Camponotus (Tanaemyrmex) sp. & 4 & 2 \\
\hline \multicolumn{3}{|c|}{ Dolichoderinae } \\
\hline Azteca instabilis (Smith) & 19 & 0 \\
\hline Azteca sp. & 14 & 0 \\
\hline Dorymyrmex sp.1 & 0 & 6 \\
\hline \multicolumn{3}{|c|}{ Pseudomyrmecinae } \\
\hline Pseudomyrmex gracilis (Fabricius) & 0 & 14 \\
\hline Pseudomyrmex pира (Forel) & 0 & 2 \\
\hline Pseudomyrmex termitarius (Smith) & 0 & 1 \\
\hline Pseudomyrmex tenuissimus (Emery) & 7 & 2 \\
\hline Pseudomyrmex rufiventris (Forel) & 1 & 4 \\
\hline Pseudomyrmex sp. gp. Pallidus & 1 & 4 \\
\hline \multicolumn{3}{|c|}{ Ponerinae } \\
\hline Pachycondyla inversa (Smith) & 1 & 0 \\
\hline Pachycondyla villosa (Fabricius) & 3 & 0 \\
\hline
\end{tabular}


(e.g., active EFNs) and, preferentially, carefully choosing the species of plants, as phylogeny and genetic distance have a known influence in herbivore communities $[51,52]$.

Most studies about ant-hemipteran associations do not take into account records of ants on plants during periods of absence of these sap-sucking insects. Nevertheless they feed on young tissues of the host plant $[9,21,22,42,43]$, so plant phenology has a direct effect on their occurrence and their potential association with ants. Solanum lycocarpum continuously produces leaves that are consumed by treehoppers practically throughout the year, while $R$. montana produces leaves roughly around September and November, period when its main sap-sucking insect, the myrmecophilous hemipteran, Rotundicerus sp., achieves its development and leaves the host plants. In any case, both plant species are patrolled by ants in the absence of their main hemipteran resources and other apparent ones. Plant phenology and seasonality have an effect on availability of resources exploited by tree-dwelling ants, producing a dynamics of niches occupied by a turnover of ant species. This yearly variation can reveal the strength of mutualistic associations between ants and myrmecophilous hemipterans and plants with or without EFNs, being important to understand the patterns of ant-plant-herbivore interactions.

\section{Acknowledgments}

The authors thank Ecology Graduate Program, technicians of the Tri Trophics Interaction laboratory, the University of Brasília-Fazenda Agua Limpa for the infrastructure, and Dr. Mundayatan Haridasan (Universidade de Brasília) who made suggestions and corrections in the manuscript. J. Maravalhas received Scientific Initiation scholarship from PIBIC/CNPq-UnB; J. H. C. Delabie acknowledges his research grant from $\mathrm{CNPq}$.

\section{References}

[1] V. Rico-Gray and P. S. Oliveira, The Ecology and Evolution of Ant-Plant Interactions, Chicago Press, Chicago, Ill, USA.

[2] J. H. Schoereder, T. G. Sobrinho, M. S. Madureira, C. R. Ribas, and P. S. Oliveira, "The arboreal ant community visiting extrafloral nectaries in the Neotropical cerrado savanna," Terrestrial Arthropod Reviews, vol. 3, pp. 3-27, 2010.

[3] P. Klimes, M. Janda, S. Ibalim, J. Kua, and V. Novotny, "Experimental suppression of ants foraging on rainforest vegetation in New Guinea: testing methods for a whole-forest manipulation of insect communities," Ecological Entomology, vol. 36, no. 1, pp. 94-103, 2011.

[4] A. V. L. Freitas and P. S. Oliveira, "Ants as selective agents on herbivore biology: effects on the behaviour of a nonmyrmecophilous butterfly," Journal of Animal Ecology, vol. 65, no. 2, pp. 205-210, 1996.

[5] A. Floren, A. Biun, and K. Eduard Linsenmair, "Arboreal ants as key predators in tropical lowland rainforest trees," Oecologia, vol. 131, no. 1, pp. 137-144, 2002.

[6] G. W. Fernandes, M. Fagundes, M. K. B. Greco, M. S. Barbeitos, and J. C. Santos, "Ants and their effects on an insect herbivore community associated with the inflorescences of Byrsonima crassifolia (Linnaeus) H.B.K. (Malpighiaceae)," Revista Brasileira de Entomologia, vol. 49, pp. 264-269, 2005.

[7] M. Heil and D. McKey, "Protective ant-plant interactions as model systems in ecological and evolutionary research," Annual Review of Ecology, Evolution, and Systematics, vol. 34, pp. 425-453, 2003.

[8] J. A. Rudgers and S. Y. Strauss, "A selection mosaic in the facultative mutualism between ants and wild cotton," Proceedings of the Royal Society B, vol. 271, no. 1556, pp. 24812488, 2004.

[9] D. McKey, L. Gaume, C. Brouat et al., "The trophic structure of tropical ant-plant-herbivore interactions: community consequences and coevolutionary dynamics," in Biotic Interactions in the Tropics: Their Role in the Maintenance of Species Diversity, D. Burslem, M. Pinard, and S. Hartley, Eds., pp. 386413, Cambridge University Press, Cambridge, UK, 2005.

[10] J. P. R. Guimarães, V. Rico-Gray, P. Oliveira, T. J. Izzo, S. F. dos Reis, and J. N. Thompson, "Interaction intimacy affects structure and coevolutionary dynamics in mutualistic networks," Current Biology, vol. 17, no. 20, pp. 1-7, 2007.

[11] L. A. Kaminski, A. V. L. Freitas, and P. S. Oliveira, "Interaction between mutualisms: ant-tended butterflies exploit enemyfree space provided by ant-treehopper associations," American Naturalist, vol. 176, no. 3, pp. 322-334, 2010.

[12] J. E. Tobin, "Ants as primary consumers: diet and abundance in the formicidae," in Nourishment and Evolution in Insect Societies, J. H. Hunt and C. A. Napela, Eds., pp. 279-307, Westview Press, Boulder, Colo, USA, 1994.

[13] J. H. C. Delabie, "Trophobiosis between formicidae and hemiptera (sternorrhyncha and auchenorrhyncha): an overview," Neotropical Entomology, vol. 30, no. 4, pp. 501-516, 2001.

[14] D. W. Davidson, S. C. Cook, R. R. Snelling, and T. H. Chua, "Explaining the abundance of ants in lowland tropical rainforest canopies," Science, vol. 300, no. 5621, pp. 969-972, 2003.

[15] P. S. Oliveira and H. F. Leitão-Filho, "Extrafloral nectaries: their taxonomic distribution and abundance in the woody flora of Cerrado vegetation in Southeast Brazil," Biotropica, vol. 19, pp. 140-148, 1987.

[16] P. S. Oliveira and A. T. Oliveira-Fliho, "Distribution of extrafloral nectaries in the woody flora of tropical communities in Western Brazil," in Plant-Animal Interactions: Evolutionary Ecology in Tropical and Temperate Regions, P. W. Price, T. M. Lewinsohn, G. Fernandes, and W. W. Benson, Eds., pp. 163-175, John Wiley and Sons, New York, NY, USA, 1991.

[17] C. R. Ribas, J. H. Schoereder, M. Pic, and S. M. Soares, "Tree heterogeneity, resource availability, and larger scale processes regulating arboreal ant species richness," Austral Ecology, vol. 28, no. 3, pp. 305-314, 2003.

[18] G. D. V. Marques and K. Del-Claro, "The ant fauna in a cerrado area: the influence of vegetation structure and seasonality (Hymenoptera: Formicidae)," Sociobiology, vol. 47, no. 1, pp. 1-18, 2006.

[19] R. I. Campos, C. T. Lopes, W. C. S. Magalhães, and H. L. Vasconcelos, "Estratificação vertical de formigas em Cerrado strictu sensu no Parque Estadual da Serra de Caldas Novas, Goiás, Brasil,” Iheringia, vol. 98, no. 3, pp. 311-316, 2008.

[20] P. S. Oliveira and A. V. L. Freitas, "Ant-plant-herbivore interactions in the neotropical cerrado savanna," Naturwissenschaften, vol. 91, no. 12, pp. 557-570, 2004.

[21] J. Maravalhas and H. C. Morais, "Association between ants and a leafhopper (Cicadellidae: Idiocerinae) in the central brazilian cerrado," Florida Entomologist, vol. 92, no. 4, pp. 563-568, 2009. 
[22] V. S. S. Moreira and K. Del-Claro, "The outcomes of an ant-treehopper association on Solanum lycocarpum St. Hill: increased membracid fecundity and reduced damage by chewing herbivores," Neotropical Entomology, vol. 34, no. 6, pp. 881-887, 2005.

[23] J. A. Ratter, S. Bridgewater, J. F. Ribeiro, T. A. Borges, and M. R. Silva, "Estudo preliminar da distribuição das espécies lenhosas da fitofisionomia cerrado sentido restrito nos estados compreendidos pelo bioma Cerrado," Boletim do Herbário Ezechias Paulo Heringer, vol. 5, pp. 5-43, 2000.

[24] A. C. Franco, M. Bustamante, L. S. Caldas et al., "Leaf functional traits of Neotropical savanna trees in relation to seasonal water deficit," Trees, vol. 19, no. 3, pp. 326-335, 2005.

[25] E. Lenza and C. A. Klink, "Comportamento fenológico de espécies lenhosas em um cerrado sentido restrito de Brasília, DF," Revista Brasileira de Botanica, vol. 29, no. 4, pp. 627-638, 2006.

[26] P. E. Oliveira, P. E. Gibbs, and A. A. Barbosa, "Moth pollination of woody species in the Cerrados of Central Brazil: a case of so much owed to so few?" Plant Systematics and Evolution, vol. 245, no. 1-2, pp. 41-54, 2004.

[27] A. Bendicho-López, H. C. Morais, J. D. Hay, and I. R. Diniz, "Lepidópteros folívoros em Roupala montana Aubl. (Proteaceae) no cerrado sensu stricto," Neotropical Entomology, vol. 35, no. 2, pp. 182-191, 2006.

[28] L. A. Kaminski, "Polyphagy and obligate myrmecophily in the butterfly Hallonympha paucipuncta (Lepidoptera: Riodinidae) in the neotropical cerrado savanna," Biotropica, vol. 40, no. 3, pp. 390-394, 2008.

[29] N. A. P. Silva, Biologia de lagartas de lycaenidae em inflorescências de plantas no cerrado do Brazil Central, M.S. thesis, Universidade de Brasília, Brasília, Brazil, 2011.

[30] A. T. Oliveira-Filho and L. C. A. Oliveira, "Biologia floral de Solanum lycocarpum St. Hil. (Solanaceae) em Larvras, MG," Revista Brasileira de Botânica, vol. 11, pp. 23-32, 1988.

[31] J. A. Lombardi and J. C. Motta-Junior, "Seed dispersal of Solanum lycocarpum St. Hil. (Solanaceae) by the maned wolf, Chysocyon brachyurus Illiger (Mammalia, Canidae)," Ciência e Cultura, vol. 45, pp. 126-127, 1993.

[32] S. R. M. Elias, R. M. Assis, E. Stacciarini-Seraphin, and M. H. Rezende, "Anatomia foliar em plantas jovens de Solanum lycocarpum A.St.-Hil. (Solanaceae)," Revista Brasileira de Botânica, vol. 26, pp. 169-174, 2033.

[33] I. R. Diniz and H. C. Morais, unpublished data.

[34] A. L. T. Souza, G. W. Fernandes, J. E. Cortes Figueira, and M. O. Tanaka, "Natural history of a gall-inducing weevil Collabismus clitellae (coleoptera: Curculionidae) and some effects on its host plant Solanum lycocarpum (Solanaceae) in Southeastern Brazil," Annals of the Entomological Society of America, vol. 91, no. 4, pp. 404-409, 1998.

[35] J. C. Dalponte and E. S. Lima, "Disponibilidade de frutos e a dieta de Lycalopex vetulus (Carnivora) em um cerrado do Mato Grosso, Brasil," Revista Brasileira de Botânica, vol. 22, pp. 325332, 1999.

[36] L. M. S. Aguiar, "Primeiro registro do uso de folhas de Solanum lycocarpum (Solanaceae) e de frutos de Emmotum nitens (Icacinaceae) por Platyrrhinus lineatus (E. Geoffroy) (Chiroptera, Phyllostomidae) no Cerrado brasileiro," Revista Brasileira de Zoologia, vol. 22, pp. 509-510, 2005.

[37] D. C. Briani and J. P. R. Guimaraes, "Seed predation and fruit damage of Solanum lycocarpum (Solanaceae) by rodents in the cerrado of central Brazil," Acta Oecologica, vol. 31, no. 1, pp. 8-12, 2007.
[38] L. Sousa-Souto, J. H. Schoereder, and C. E. G. R. Schaefer, "Leaf-cutting ants, seasonal burning and nutrient distribution in Cerrado vegetation," Austral Ecology, vol. 32, no. 7, pp. 758765, 2007.

[39] R. K. Colwell, "EstimateS: statistical estimation of species richness and shared species from samples. Version 8.0.0 User's Guide and Application," 2008, http://viceroy.eeb.uconn .edu/estimates.

[40] M. Ayres, M. Ayres Jr., D. L. Ayres, and A. A. S. Santos, BioEstat 5.0, Instituto de Desenvolvimento Sustentável Mamirauá, Belém, Brazil, 2005.

[41] V. Rico-Gray, J. G. García-Franco, M. Palacios-Rios, C. DiazCastelazo, V. Parra-Tabla, and J. A. Navarro, "Geographical and seasonal variation in the richness of ant-plant interactions in Mexico," Biotropica, vol. 30, no. 2, pp. 190-200, 1998.

[42] B. C. Lopes, "Treehoppers (Homoptera: Membracidae) in the Southeast Brazil: use of host plants," Revista Brasileira de Zoologia, vol. 12, pp. 595-608, 1995.

[43] K. Del-Claro and P. S. Oliveira, "Ant-homoptera interactions in a neotropical savanna: the honeydew-producing treehopper, Guayaquila xiphias (Membracidae), and its associated ant fauna on Didymopanax vinosum (Araliaceae)," Biotropica, vol. 31, no. 1, pp. 135-144, 1999.

[44] H. C. P. Silveira, P. S. Oliveira, and J. R. Trigo, "Attracting predators without falling prey: chemical camouflage protects honeydew-producing treehoppers from ant predation," American Naturalist, vol. 175, no. 2, pp. 261-268, 2010.

[45] C. V. A. Dansa, Estratégia de forrageamento de pseudomyrmex gracilis (Fabr.) (Hymenoptera, Formicidae), M.S. thesis, Universidade Estadual de Campinas, Campinas, Brazil, 1989.

[46] H. G. Fowler, L. C. Forti, C. R. F. Brandão, J. H. C. Delabie, and H. L. Vasconcelos, "Ecologia nutricional de formigas," in Ecologia Nutricional de Insetos e Suas Implicações no Manejo de Pragas, A. R. Panizzians and J. R. P. Parra, Eds., pp. 131-223, Editora Manole e CNPq, São Paulo, Brazil, 1991.

[47] M. A. S. De La Fuente and R. J. Marquis, "The role of anttended extrafloral nectaries in the protection and benefit of a neotropical rainforest tree," Oecologia, vol. 118, no. 2, pp. 192202, 1999.

[48] R. Cogni, A. V. L. Freitas, and P. S. Oliveira, "Interhabitat differences in ant activity on plant foliage: ants at extrafloral nectaries of Hibiscus pernambucensis in sandy and mangrove forests," Entomologia Experimentalis et Applicata, vol. 107, no. 2, pp. 125-131, 2003.

[49] A. D. Gove, J. D. Majer, and V. Rico-Gray, "Ant assemblages in isolated trees are more sensitive to species loss and replacement than their woodland counterparts," Basic and Applied Ecology, vol. 10, no. 2, pp. 187-195, 2009.

[50] F. S. Neves, R. F. Braga, M. M. Do EspíritoSanto, J. H. C. Delabie, G. W. Fernandes, and G. A. Sánchez-Azofeifa, "Diversity of arboreal ants in a brazilian tropical dry forest: effects of seasonality and successional stage," Sociobiology, vol. 56, no. 1, pp. 177-194, 2010.

[51] G. D. Weiblen, C. O. Webb, V. Novotny, Y. Basset, and S. E. Miller, "Phylogenetic dispersion of host use in a tropical insect herbivore community," Ecology, vol. 87, no. 7, pp. 62-75, 2006.

[52] H. C. Morais, E. R. Sujii, M. Almeida-Neto, P. S. de Carvalho, J. D. V. Hay, and I. R. Diniz, "Host plant specialization and species turnover of caterpillars among hosts in the Brazilian Cerrado," Biotropica, vol. 43, no. 4, pp. 467-472, 2011. 

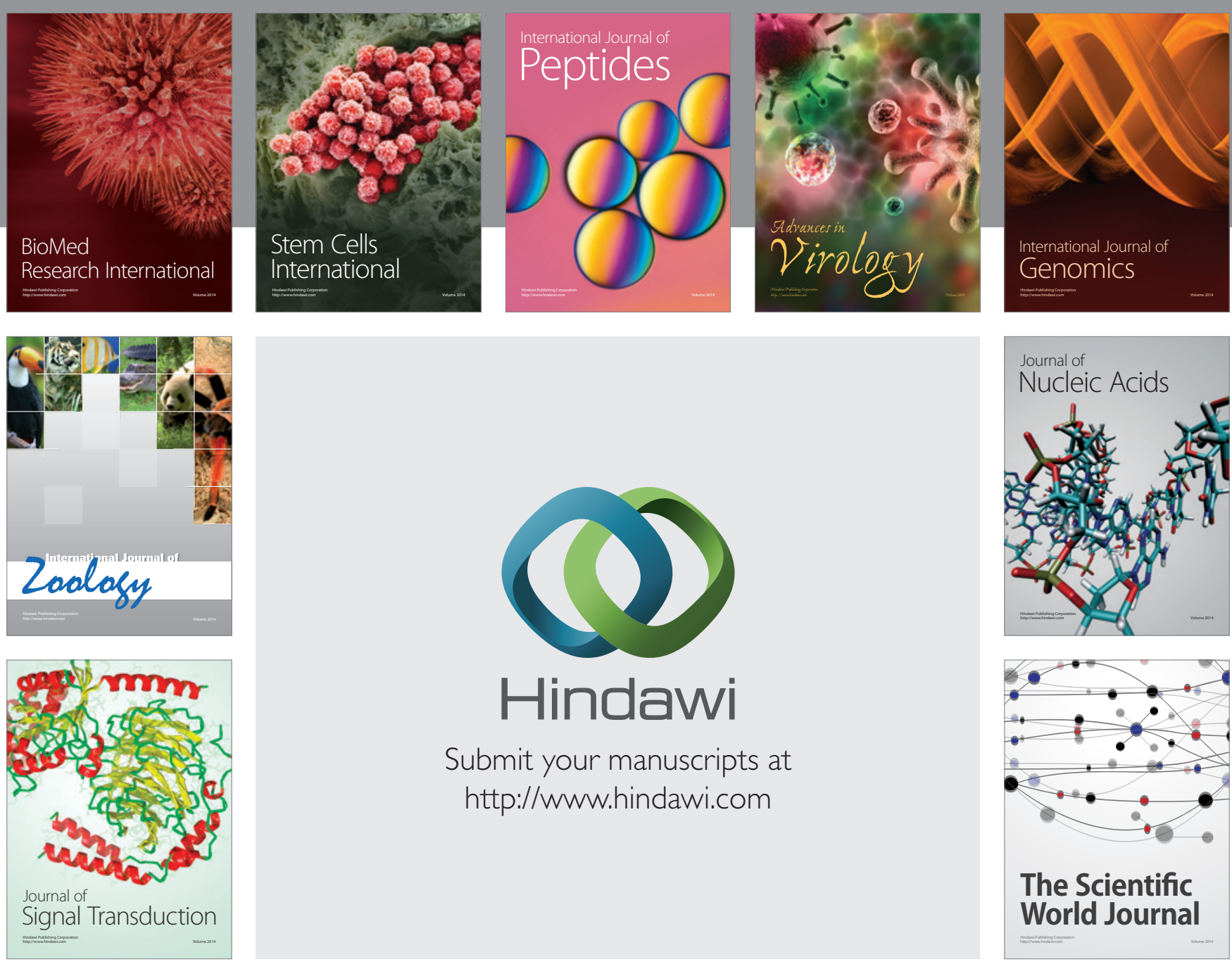

Submit your manuscripts at

http://www.hindawi.com
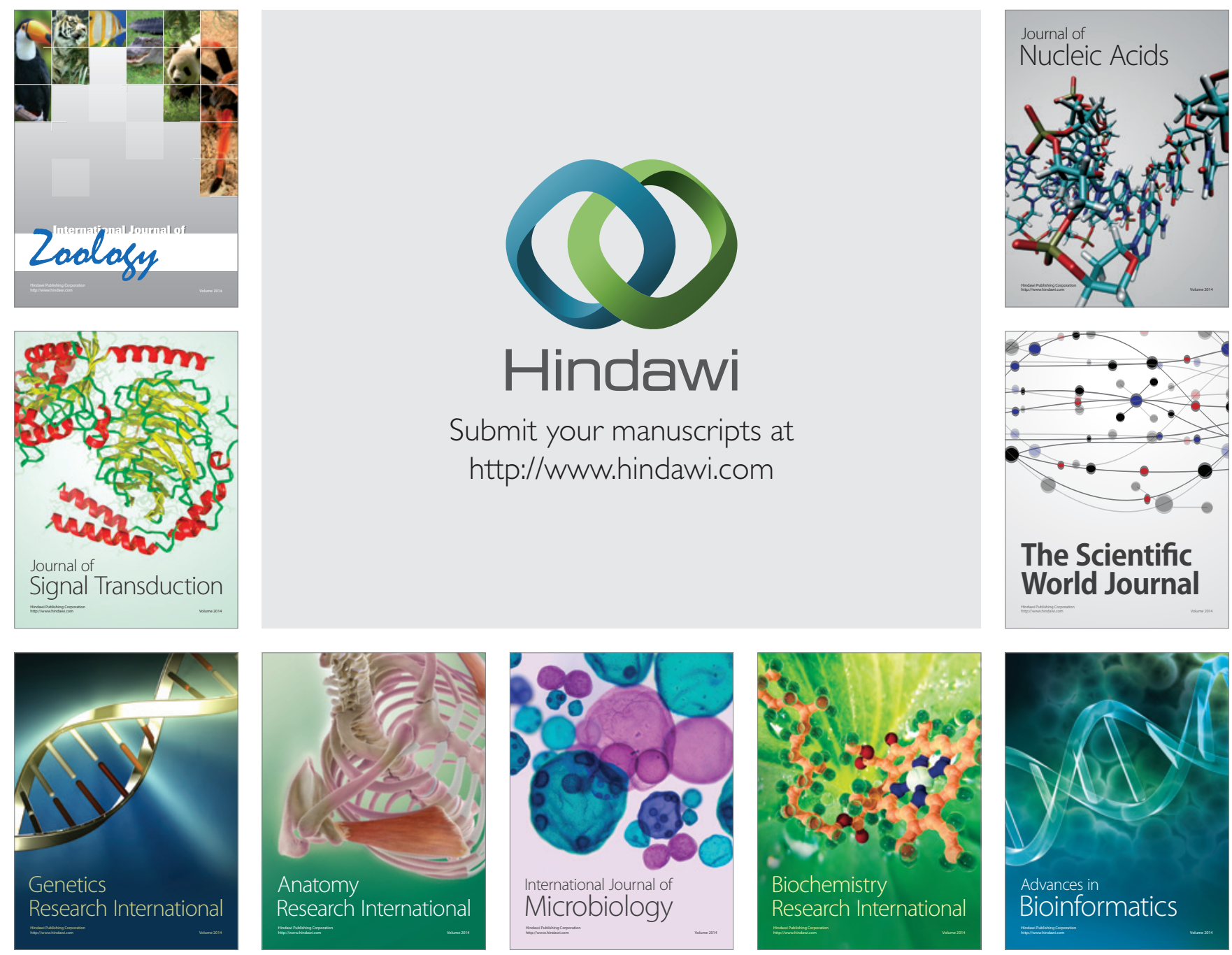

The Scientific World Journal
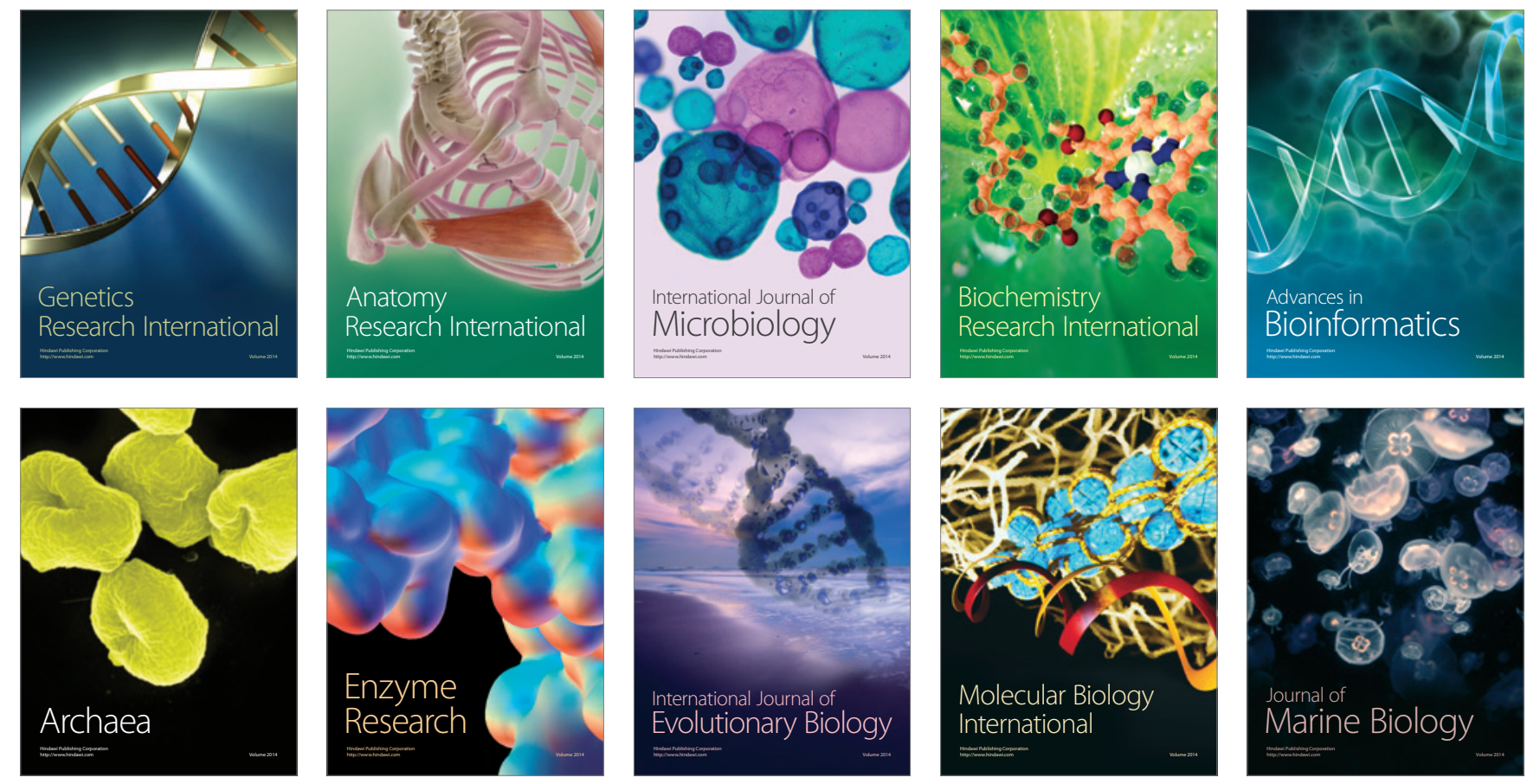